\title{
Interaction between saflufenacil and imazapyr+imazapic in the management of barnyardgrass and weedy rice and selectivity for irrigated rice
}

\author{
Ânderson da Rosa Feijó ${ }^{*}$ (D) Marcus Vinicius Fipke ${ }^{1}$ Luiza Piccinini Silveira $^{1}$ \\ Edinalvo Rabaioli Camargo ${ }^{1}$ Nelson Diehl Kruse ${ }^{2}$ Luis Antonio de Avila ${ }^{1}$
}

${ }^{1}$ Centro de Herbologia (CEHERB), Universidade Federal Pelotas (UFPel), 96160-000, Capão do Leão, RS, Brasil. E-mail: andersonrfeijo@gmail.com. "Corresponding author.

${ }^{2}$ Universidade Federal de Santa Maria (UFSM), Santa Maria, RS, Brasil.

\begin{abstract}
The use of imidazolinone-tolerant rice cultivars allows selective control of weedy rice and barnyardgrass. However, in many situations, there is a need to add herbicides from other chemical groups to increase the spectrum of weed control. In this sense, saflufenacil has the potential to be used in mixture with imidazolinone herbicides. This study aimed to evaluate the interaction effects of the imazapyr+imazapic and safufenacil herbicides in weedy rice and barnyardgrass and to investigate their impacts on the yield of the irrigated rice cultivar Puitá INTA CL. To reach these aims, greenhouse and field experiments were carried out during two growing seasons, with herbicide treatments sprayed separately and in mixtures of saflufenacil with imazapyr+imazapic. Results showed that saflufenacil did not interfere with control of weedy rice and barnyardgrass obtained with imazapyr+imazapic. The $D_{50}$ values of imazapyr+imazapic for weedy rice control were $14.5+5,9.1+3$ and $12.5+4.2 \mathrm{~g} \mathrm{ha}$ of imazapyr+imazapic for combinations with 0, 3.06 and $6.12 \mathrm{~g} \mathrm{ha}$ of saflufenacil, respectively. In the field experiments, all doses of imazapyr+imazapic applied isolated or in mixture with saftufenacil provided control levels barnyardgrass above $90 \%$ at 28 days after herbicides application. Furthermore, safufenacil did not cause damage or loss in the yield of the rice crop when mixed with imazapyr+imazapic. The Puitá INTA CL rice cultivar was tolerant of the tested herbicides, whether applied alone or in mixture, reaching grain yield of $9.987 \mathrm{~kg} \mathrm{ha}^{-1}$ when applied $42 \mathrm{~g} \mathrm{ha} a^{-1}$ of saflufenacil plus $147+49 \mathrm{~g} \mathrm{ha}$-1 of imazapyr+imazapic.
\end{abstract}

Key words: herbicides, imidazolinone, pyrimidinedione, Oryza sativa.

Interação entre saflufenacil e imazapyr+imazapic no manejo de capim-arroz e arroz-daninho e a seletividade para cultura do arroz irrigado

RESUMO: A utilização de cultivares de arroz tolerantes às imidazolinonas possibilita um controle seletivo de arroz-daninho. No entanto, em muitas situações existe a necessidade de adição de herbicidas de outros grupos químicos para aumentar o espectro de controle de plantas daninhas. Neste sentido, saflufenacil apresenta potencial para ser utilizado em mistura com herbicidas imidazolinonas. Este estudo teve como objetivo avaliar os efeitos da interação dos herbicidas imazapyr+imazapic e saflufenacil em arroz-daninho e capim-arroz; e averiguar os impactos sobre a produtividade do cultivar de arroz irrigado Puitá INTA CL. Para alcançar esses objetivos, foram realizados experimentos em casa de vegetação e a campo em duas estações de cultivo, com os tratamentos herbicidas aplicados separadamente e em misturas de saflufenacil com imazapyr+imazapic. Os resultados mostraram que a adição de saflufenacil não interferiu no controle de arroz-daninho e capim-arroz obtido com imazapyr+imazapic. Os valores $D_{50}$ de imazapyr+imazapic para o controle de arroz-daninho foram $14,5+5 ; 9,1+3$ e 12,5+4,2 $\mathrm{g} \mathrm{ha}{ }^{-1}$ de imazapyr+imazapic para combinações com 0; 3,06 e 6,12 $\mathrm{g}$ ha $\mathrm{h}^{-1}$ de saflufenacil. No experimento de campo todas doses de imazapyr+imazapic, aplicadas isoladas ou em mistura, proveram niveis de controle de capim-arroz superiores a $90 \%$ aos 28 dias após a aplicação dos herbicidas. Além disso, saflufenacil não causou injúrias ou perda de rendimento da cultura do arroz quando misturado com imazapyr+imazapic. O cultivar Puitá INTA CL foi tolerante aos herbicidas testados, sejam aplicados isolados ou em mistura, atingindo uma produtividade de $9.987 \mathrm{Kg} \mathrm{ha}^{-1}$ quando aplicado $42 \mathrm{~g} \mathrm{ha}^{-1}$ de saflufenacil mais $147+49 \mathrm{~g} \mathrm{ha} \mathrm{I}^{-1}$ de imazapyr+imazapic.

Palavras-chave: herbicidas, imidazolinona, pirimidinadiona, Oryza sativa.

\section{INTRODUCTION}

The Clearfield ${ }^{\circledR}$ system has become an indispensable tool for selective control of Poaceae weed species, as weedy rice and barnyardgrass. In this system, imidazolinone-resistant cultivars are grown with the application of imidazolinone herbicides in pre and/or post-emergence (IRGA, 2018; SOSBAI,
2018). However, the intensive adoption and misuse of this technology has led to the selection of resistant weeds, not only the weedy rice (Oryza sativa) but also the barnyardgrass (Echinochloa crus-galli) and giant arrowhead (Sagittaria montevidensis); and this has led the use of other herbicides to control these species (MENEZES et al., 2013; MOURA et al., 2016; NUNES et al., 2016; HEAP, 2018). 
Thus, some changes have been established to aid in the chemical management, among them, the herbicide mixture, which aims to increase action spectrum and efficiency of weed control, such as red rice (Oryza sativa), Echinochloa crus-galli, Sesbania exaltata, Ipomoea hederacea, Alternanthera philoxeroides (PELLERIN et al., 2003; PELLERIN et al., 2004; CARLSON et al., 2011; MONTGOMERY et al., 2015; FISH et al., 2016). The herbicides mixtures can result in three different types of interactions, which can be an additive, synergistic or antagonistic interaction. These interactions can occur due to mechanisms such as changes in the amount of an herbicide that reaches its sites of action through molecules absorption, translocation or metabolism changes, also can be due interaction at the site action between the herbicides, where one herbicide affects the binding of the other at its site of action. In addition, the interaction of herbicides mixture can produce opposite effects on the same physiological process of the plant or synergizes the overall effect (COLBY, 1967; DAMALAS，2004; KUDSK \& MATHIASSEN, 2004).

The tank mixture has low cost since it requires a single application; besides, it reduces possible mechanical damages to the crop (PETTER et al., 2012). Thus, it has been a usual practice in the face of its recent regularization in Brazil. However, its use requires specific knowledge about the products applied and the final result of chemical reactions during mixing. Several possibilities of herbicide mixtures have emerged to aid in the control of resistant species, including the increasing use of herbicides that are unusual in rice farming, like the saflufenacil (CAMARGO et al., 2012a).

Saflufenacil is an herbicide belonging to the chemical group of pyrimidinediones, acting in the inhibition of the Protoporphyrinogen IX oxidase (Protox). Among its characteristics are the absorption both by roots and leaves, translocation via xylem and phloem (LIEBLet al., 2008; SOLTANI et al., 2009; KNEZEVICet al., 2010), and efficiency in the control of wide range dicot weeds, such as Solanum nigrum, and Ipomoea purpurea (GROSSMANN et al., 2011), Amaranthus retroflexus, Abutilon theophrasti, and Polygonum persicaria (SOLTANI et al., 2009), Conyza canadensis (KUMAR et al., 2017), Conyza sumatrensis and Bidens pilosa (VARGAS et al., 2019). The registration of this herbicide is recent, and it has been indicated for pre and post-emergence applications in irrigated rice crops (MONTGOMERYet al., 2014). In this context, saflufenacil allows controlling a higher number of weed species, for which the herbicides belonging to the Clearfield ${ }^{\circledR}$ technology are not efficient, such as, for example biotypes Sagittaria montevidensis resistant to imidazolinone herbicides (MOURA et al., 2015), and Aeschynomene spp. a problematic weed, less responsive to most herbicides labeled in rice (LAZAROTO et al., 2008; CONCENÇO et al., 2018; MILLER \& NORSWORTHY, 2018). However, there is little information in the literature on the effects of the interaction between these herbicides (CAMARGO et al., 2012b; MONTGOMERY et al., 2015; WALSH et al., 2015).

The antagonistic effect between ALS and Protox-inhibiting herbicides, more specifically for diphenyl ether group, is known. The combination of imazamox with fomesafen, lactofen, or acifluorfen reduced the control of Ipomoea hederacea and Abutilon theophrasti (UNLAND et al., 1999). The control of Setaria faberi was reduced 14 and $33 \%$ when lactofen was mixed with imazamox and imazethapyr, respectively, in comparison to the herbicides applied alone. Similar results were obtained when acifluorfen or fomesafen with imazamox and imazethapyr were mixed (NELSON et al., 1998). The antagonism was due to reduced absorption and translocation of the herbicides imazamox and imazethapyr in the plants, due to the activity of the diphenyl ethers which limited this effect (NELSON et al., 1998; UNLAND et al., 1999). These results may be explained by the difference in the time of phytotoxic action of the two classes of herbicides. The PPO inhibitor herbicides act quickly, resulting in the loss of integrity of cell membranes, caused by the peroxidation of the plasma membrane (DAYAN \& WATSON, 2011). Therefore, the destruction of epidermal cells reduced the absorption and translocation of systemic herbicides, such as imidazolinones.

Saflufenacil has physicochemical properties, such as weak acid character, $\mathrm{pK}_{\mathrm{a}}$, and $\mathrm{K}_{\mathrm{ow}}$ of 4.4 and 2.6, respectively, that provide a higher capacity in plant mobility than the herbicides of the diphenyl ether group. The metabolic stability of saflufenacil in the weeds may also explain its systemic mobility behavior (GROSSMANN et al., 2011), facts that can differentiate the results commonly reported in the literature of the mixture of Protox inhibitors with imidazolinones. Contrasting the findings of the interaction between Protox inhibitors and the imidazolinone group, recent studies have shown a synergistic effect in the mixture of imazethapyr and saflufenacil, which resulted in increased control of barnyardgrass and red rice in $15 \%$ and $18 \%$, respectively, when compared with the separate 
application of imazethapyr (CAMARGO et al., 2012a; MONTGOMERY et al., 2015). The synergistic effect was related to the increase of $30 \%$ in absorption and $35 \%$ in the translocation of this herbicide mix in the weedy rice plants when compared to the application of imazethapyr alone (CAMARGO et al., 2012b). However, this mixture injured rice crops; although, no reduction in yield was observed (CAMARGO et al., 2012a). It is important to emphasize that the studies mentioned above were conducted with imazethapyr and not with the commercial mixture of imazapyr+imazapic.

Through the regularization of herbicide tank mixtures and the increasing use of this new Protox-inhibiting herbicide in rice crops, there is a need to understand the interaction between saflufenacil and imidazolinone herbicides. Thus, this research aimed to evaluate the interaction effects of the imazapyr+imazapic and saflufenacil herbicides in the post-emergence of weedy rice and barnyardgrass, and to investigate their impacts on the Puitá INTA CL irrigated rice cultivar.

\section{MATERIALS AND METHODS}

Greenhouse and field conditions were evaluated in this study. For the greenhouse experiment, sensitive weedy rice (Oryza sativa) seeds were used as an indicator species for imazapyr+imazapic. The seeds were sown in $750 \mathrm{~mL}$ plastic pots, with Albaquafsoil, sandy-loam texture class. After emergence, six plants were maintained per pot. The basic fertilization was performed using 20,75 , and $75 \mathrm{~kg} \mathrm{ha}^{-1}$ of nitrogen $(\mathrm{N})$, phosphorus pentoxide $\left(\mathrm{P}_{2} \mathrm{O}_{5}\right)$, and potassium oxide $\left(\mathrm{K}_{2} \mathrm{O}\right)$, respectively. The $\mathrm{N}$ cover and fertilization were carried out one day before the beginning of flooding irrigation (V3-V4 stages), at the rate of $40 \mathrm{~kg} \mathrm{~N} \mathrm{ha}^{-1}$ (COUNCE et al., 2000). The experiment was conducted in a completely randomized design with four replicates, with each pot corresponding to a replicate.

The treatments consisted of imazapyr+imazapic and saflufenacil combinations (Table 1). One isolated dose of each herbicide and a mixture with two sub-doses of the two herbicides were used. This procedure was conducted to investigate the interaction effect without the overlap of symptoms in plants. A nonionic adjuvant $(0.5 \% \mathrm{v} / \mathrm{v})$ was added to the herbicides. The treatments were applied in post-emergence at the V4 stage (SOSBAI, 2014). Herbicides were applied with a $\mathrm{CO}_{2}$-pressurized backpack sprayer using TeeJet XR 110015 at 1.4 bar pressure, resulting in an output of $150 \mathrm{~L} \mathrm{ha}^{-1}$.

Table 1 - Doses of the herbicide treatments with imazapyr+imazapic and saflufenacil applied alone and mixture in the greenhouse experiment.

\begin{tabular}{|c|c|c|c|}
\hline & \multicolumn{3}{|c|}{ 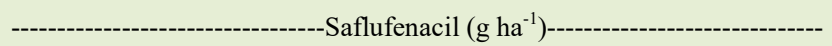 } \\
\hline & 0 & 3.06 & 6.12 \\
\hline \multirow{10}{*}{ Imazapyr+Imazapic $\left(\mathrm{g} \mathrm{ha}^{-1}\right)$} & 0 & 0 & 0 \\
\hline & $9.2+3.06$ & $9.2+3.06$ & $9.2+3.06$ \\
\hline & $18.4+6.12$ & $18.4+6.12$ & $18.4+6.12$ \\
\hline & $36.75+12.25$ & $36.75+12.25$ & $36.75+12.25$ \\
\hline & $73.5+24.5$ & $73.5+24.5$ & $73.5+24.5$ \\
\hline & $147+49$ & $147+49$ & $147+49$ \\
\hline & $294+98$ & $294+98$ & $294+98$ \\
\hline & $588+196$ & $588+196$ & $588+196$ \\
\hline & \multicolumn{3}{|c|}{---------------------------Imazapyr+Imazapic $\left(\mathrm{g} \mathrm{ha}^{-1}\right)$----------------------- } \\
\hline & 0 & $9.2+3.06$ & $18.4+6.12$ \\
\hline \multirow{8}{*}{ Saflufenacil $\left(\mathrm{g} \mathrm{ha}^{-1}\right)$} & 0 & 0 & 0 \\
\hline & 3.06 & 3.06 & 3.06 \\
\hline & 6.12 & 6.12 & 6.12 \\
\hline & 12.25 & 12.25 & 12.25 \\
\hline & 24.5 & 24.5 & 24.5 \\
\hline & 49 & 49 & 49 \\
\hline & 98 & 98 & 98 \\
\hline & 196 & 196 & 196 \\
\hline
\end{tabular}

Ciência Rural, v.50, n.7, 2020. 
The pots were flooded on the first day after herbicide application (DAA).

The visual control was accomplished onthe $35^{\text {th }} \mathrm{DAA}$, using a percentage rate that ranged from 0 (no symptoms) to $100 \%$ (all plants dead). Subsequently, the shoot dry mass (SDM) was obtained by drying the plant material with forced air circulation at $65^{\circ} \mathrm{C}$.

Field experiments were carried out at the Weed Science Center (Ceherb), Federal University of Pelotas, Capão do Leão, Rio Grande do Sul, Brazil, in the 2014/15 and 2015/16 growing seasons. The soil was classified as Albaquaf, sandy-loam textural class, with the following characteristics: $\mathrm{pH}_{\text {water }}(1: 1)=5.1$; $3.4 \mathrm{cmol} \mathrm{c} \mathrm{dm}^{-3}$ calcium; $1.8 \mathrm{cmolc} \mathrm{dm}^{-3}$ magnesium; $0.5 \mathrm{cmolc} \mathrm{dm}^{-3}$ aluminium; $11.7 \mathrm{mg} \mathrm{dm}^{-3}$ phosphorus; $43 \mathrm{mg} \mathrm{dm}{ }^{-3}$ potassium; cation exchange capacity $\mathrm{CEC}_{\mathrm{pH} 7} 9.2$, V 57.6\%; $24 \%$ clay content; $0.7 \%$ organic matter content.

In this experiment, rice seeds of the cultivar Puitá INTA CL were used, with sowing density of $120 \mathrm{~kg} \mathrm{ha}^{-1}$ in $0.17 \mathrm{~m}$ spaced rows, employing a mechanical seed drill. The infestation of barnyardgrass was carried out with spontaneous seed germination in the soil seed bank. The fertilization was performed in a row using 20,75 , and $75 \mathrm{~kg} \mathrm{ha}^{-1}$ of $\mathrm{N}, \mathrm{P}_{2} \mathrm{O}_{5}$, and $\mathrm{K}_{2} \mathrm{O}$, respectively. Nitrogen cover and fertilization were done another two times at the beginning of irrigation (V4) at the rate of $40 \mathrm{~kg} \mathrm{~N} \mathrm{ha}^{-}$ ${ }^{1}$, and at the panicle initiation stage (R0) at the rate of $80 \mathrm{~kg} \mathrm{~N} \mathrm{ha}^{-1}$ (COUNCE et al., 2000).

The experimental plots of $1.53 \times 5 \mathrm{~m}$ $\left(7.65 \mathrm{~m}^{2}\right)$ were arranged in a randomized block scheme with four replicates. The herbicide treatments consisted of the doses 21 and $42 \mathrm{~g} \mathrm{ha}^{-1}$ of saflufenacil, corresponding 30 and $60 \mathrm{~g} \mathrm{ha}^{-1}$ of commercial formulation $\mathrm{Heat}^{\mathrm{B}} \mathrm{WG}$ (BASF); and the doses $36.75+12.25 ; 73.5+24.5 ; 110.25+36.75 ; 147+49 \mathrm{~g}$ $\mathrm{ha}^{-1}$ of imazapyr+imazapic, corresponding to the commercial formulation Kifix ${ }^{\circledR}$ WG (BASF); more over, a mix application of two herbicides in the doses citedand anuntreated control (herbicide-free) were also considered. The nonionic adjuvant Dash ${ }^{\circledR}$ at $0.5 \%$ $\mathrm{v} / \mathrm{v}$ was added to the herbicides. The application of herbicides was performed as previously mentioned. The experimental area was flooded on the $1^{\text {st }} \mathrm{DAA}$. The disease and insect control were performed according to local research recommendations (SOSBAI, 2014).

The visual barnyardgrass control was conducted on the $14^{\text {th }}$ and $28^{\text {th }}$ DAA, as previously mentioned. For determination of grain yield in the maturity stage of the crop, manual harvesting was performed in $3.4 \mathrm{~m}^{2}$ of each plot. Then, the grain moisture was adjusted to $13 \%$, with grain yield expressed in $\mathrm{Kg} \mathrm{ha}^{-1}$.

\section{Data analysis}

For the experiment in the greenhouse, the data were initially tested for normality and homogeneity of variance and then subjected to analysis of variance (ANOVA). Regressions were performed by adjusting linear or non-linear models to the mean data of treatments, using Sigma Plot 12.5(Systat Software, Inc., San Jose, CA - USA). For the regression analysis, the herbicide dose was considered as an independent factor, and the variables evaluated as dependent factors. The doses required to control $50 \%$ of weedy rice $\left(\mathrm{D}_{50}\right)$ and growth reduction in $50 \%\left(\mathrm{GR}_{50}\right)$ were estimated using the regression curves of the control and SDM.

For experiments in the field, the data were initially tested for normality and homogeneity of variance. The control data were transformed using the function:

$$
y t=\operatorname{asin} \sqrt{ }(y+0.5) / 100
$$

where "yt" and " $y$ " is the transformed and untransformed control, respectively. The control and grain yield variables for each year (2014/15 and $2015 / 16$ ) were subjected to analysis of variance and, in case of significant differences among herbicide treatments, Tukey's test $(\mathrm{P} \leq 0.05)$ was performed to separate means. This process was performed with the statistical program $\mathrm{SAS}^{\circledR}$ (Statistical Analysis Systems, Software 9.2, SAS Institute Inc., Cary, NC).

\section{RESULTS AND DISCUSSION}

In the greenhouse experiment, the increment doses of imazapyr+imazapic resulted in increased weedy rice control (Figure 1A), regardless of the mixture with saflufenacil. The $\mathrm{D}_{50}$ values of imazapyr+imazapicobtained for control were 14.5+5.0 $\mathrm{g} \mathrm{ha}^{-1}$, for isolated application, and 9.1+3.0 $\mathrm{g} \mathrm{ha}^{-1}$, and 12.5+4.2 $\mathrm{g} \mathrm{ha}^{-1}$ of imazapyr+imazapicin combination with 3.06 and $6.12 \mathrm{~g} \mathrm{ha}^{-1}$ of saflufenacil, respectively (Table 2). These findings evidenced that, under these conditions, adding saflufenacil in the mixture did not interfere in the action of imazapyr+imazapic in controlling weedy rice.

The isolated saflufenacil did not result in adequate weedy rice control since the highest isolated dose applied (196 $\left.\mathrm{g} \mathrm{ha}^{-1}\right)$ lead to a control of only $20 \%$ (Figure 1B). The addition of imazapyr+imazapic subdoses in the mix with saflufenacil resulted in a control higher than $50 \%$, with no adjustment of regression equations. However, the increment of combined 
(A)

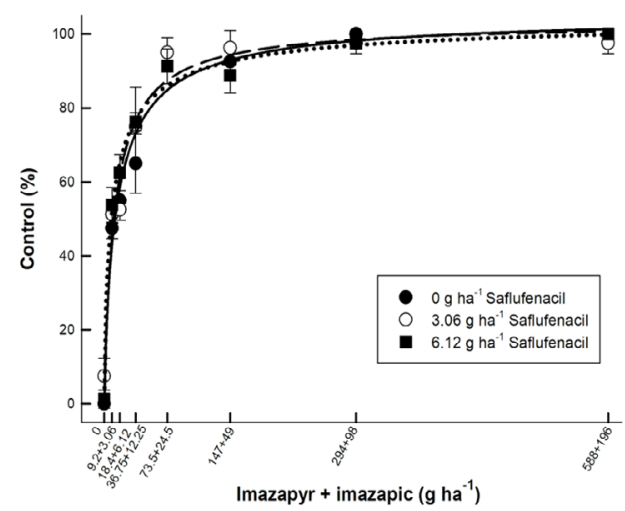

(B)

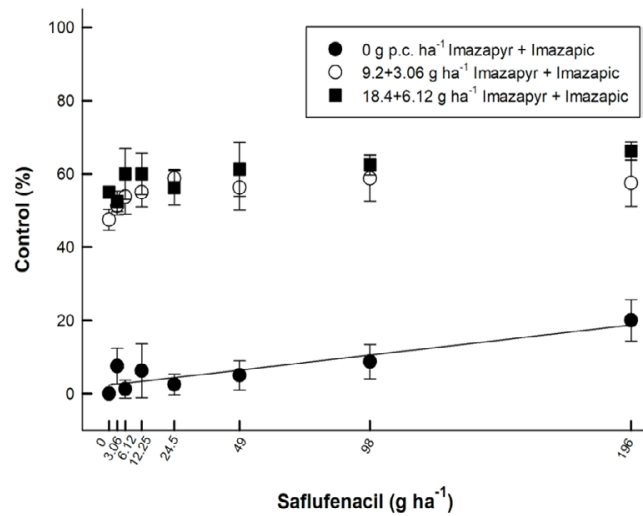

Figure 1 - Control (\%) of weedy rice plants sprayed with doses of the herbicide imazapyr+imazapic alone and mixed with saflufenacil (A); doses of saflufenacil alone and mixed with imazapyr+imazapic (B). Bars indicate the $95 \%$ confidence interval.

doses of saflufenacil did not represent an increase in weedy rice control (Figure 1B).

Regarding the SDM, when the plants were sprayed with imazapyr+imazapic doses (Figure 2A), regardless of the mixture with saflufenacil, there was a reduction in the SDM of weedy rice plants.
The association with saflufenacil did not change the SDM of weedy rice plants and showed that, under these conditions, the Protox inhibitor does not reduce the action of imidazolinones. All the $\mathrm{GR}_{50}$ estimated values for this variable $0.2+0.06,4.1+1.3$, and $0.001+0.0001 \mathrm{~g} \mathrm{ha}^{-1}$ imazapyr+imazapic (doses

Table 2 - Regression equations used to determine the effects of herbicides on weedy rice plants in mixed and isolated in tank in the 2015/16 growing season.

\begin{tabular}{|c|c|c|c|c|c|c|c|}
\hline \multirow[t]{2}{*}{${ }^{1} \mathrm{Her}$} & \multirow[t]{2}{*}{${ }^{2} \operatorname{Mix}$} & \multicolumn{6}{|c|}{ - } \\
\hline & & A & $\mathrm{b}$ & D50-GR50\#\#\# & $\mathrm{R}^{2}$ & P\#\# & Equation \\
\hline \multicolumn{8}{|c|}{ 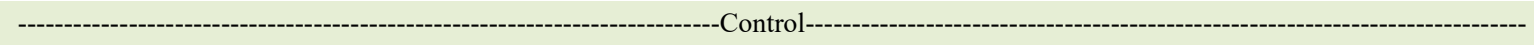 } \\
\hline $\mathrm{I}+\mathrm{I}$ & Isolated & $107.6(9.8)^{* *}$ & $-0.82(0.26)^{*}$ & $14.9+5.0^{*}$ & 96.6 & $<0.01$ & $\mathrm{y}=\mathrm{a} / 1+(\mathrm{x} / \mathrm{D} 50) \mathrm{b}$ \\
\hline $\mathrm{I}+\mathrm{I}$ & $3.06 \mathrm{~g} \mathrm{SA}$ & $104.3(5.4)^{* *}$ & $-0.74(0.16)^{* *}$ & $9.1+3.0^{* *}$ & 98.9 & $<0.01$ & $\mathrm{y}=\mathrm{a} / 1+(\mathrm{x} / \mathrm{D} 50) \mathrm{b}$ \\
\hline $\mathrm{I}+\mathrm{I}$ & $6.12 \mathrm{~g} \mathrm{SA}$ & $105.0(8.5)^{* *}$ & $-0.91(0.31)^{*}$ & $12.5+4.2^{*}$ & 95.5 & $<0.01$ & $\mathrm{y}=\mathrm{a} / 1+(\mathrm{x} / \mathrm{D} 50) \mathrm{b}$ \\
\hline SA & Isolated & $2.3(1.2) \mathrm{ns}$ & $0.08(0.01)^{* *}$ & - & 78.5 & $<0.01$ & $y=a+b^{*} x$ \\
\hline SA & $9.2 \mathrm{I}+\mathrm{I}$ & - & - & - & - & - & - \\
\hline SA & $18.4 \mathrm{I}+\mathrm{I}$ & - & - & - & - & - & - \\
\hline \multicolumn{8}{|c|}{ 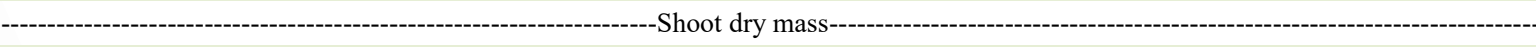 } \\
\hline $\mathrm{I}+\mathrm{I}$ & Isolated & $3.52(0.11)^{* *}$ & $0.24(0.06)^{* *}$ & $0.2+0.06 \mathrm{~ns}$ & 98.7 & $<0.01$ & $\mathrm{y}=\mathrm{a} / 1+(\mathrm{x} / \mathrm{D} 50) \mathrm{b}$ \\
\hline $\mathrm{I}+\mathrm{I}$ & $3.06 \mathrm{~g} \mathrm{SA}$ & $3.11(0.17)^{* *}$ & $0.45(0.10)^{* *}$ & $4.1+1.3 \mathrm{~ns}$ & 96.4 & $<0.01$ & $\mathrm{y}=\mathrm{a} / 1+(\mathrm{x} / \mathrm{D} 50) \mathrm{b}$ \\
\hline $\mathrm{I}+\mathrm{I}$ & $6.12 \mathrm{~g} \mathrm{SA}$ & $3.63(0.13)^{* *}$ & $0.13(0.06) \mathrm{ns}$ & $0.001+0.0 \mathrm{~ns}$ & 98.4 & $<0.01$ & $\mathrm{y}=\mathrm{a} / 1+(\mathrm{x} / \mathrm{D} 50) \mathrm{b}$ \\
\hline SA & Isolated & $3.65(0.10)^{* *}$ & $-0.007(0.0)^{* *}$ & - & 82.3 & $<0.01$ & $y=a+b^{*} x$ \\
\hline SA & $9.2 \mathrm{I}+\mathrm{I}$ & - & - & - & - & - & - \\
\hline SA & $18.4 \mathrm{I}+\mathrm{I}$ & - & - & - & - & - & - \\
\hline
\end{tabular}

\# $\mathrm{PE}=$ standard error of estimate; ${ }^{*}$ indicates $\mathrm{P}<0.05 ;{ }^{* *}$ indicates $\mathrm{P}<0.01$; ns $=$ not significant. \#\# $\mathrm{P}$ indicates the probability of the model. \#\#\# D50and GR50 indicate the dose required to promote control 50\% or growth reduction in 50\%in weedy rice, respectively.

${ }^{1} \mathrm{Her}=$ Herbicide doses. ${ }^{2} \mathrm{Mix}=$ Herbicide mixture. Isolated $=$ no mixing; $3.06 \mathrm{~g} \mathrm{SA}=$ mixture with $3.06 \mathrm{~g}$ ha-1 saflufenacil; $6.12 \mathrm{~g}$ SA $=$ mixture with $6.12 \mathrm{~g}$ ha-1 saflufenacil; $9.2 \mathrm{I}+\mathrm{I}=$ mixture with $9.2+3.06 \mathrm{~g}$ ha-1imazapyr+imazapic; $18.4 \mathrm{I}+\mathrm{I}=$ mixture with $18.4+6.12 \mathrm{~g}$ ha1imazapyr+imazapic. 


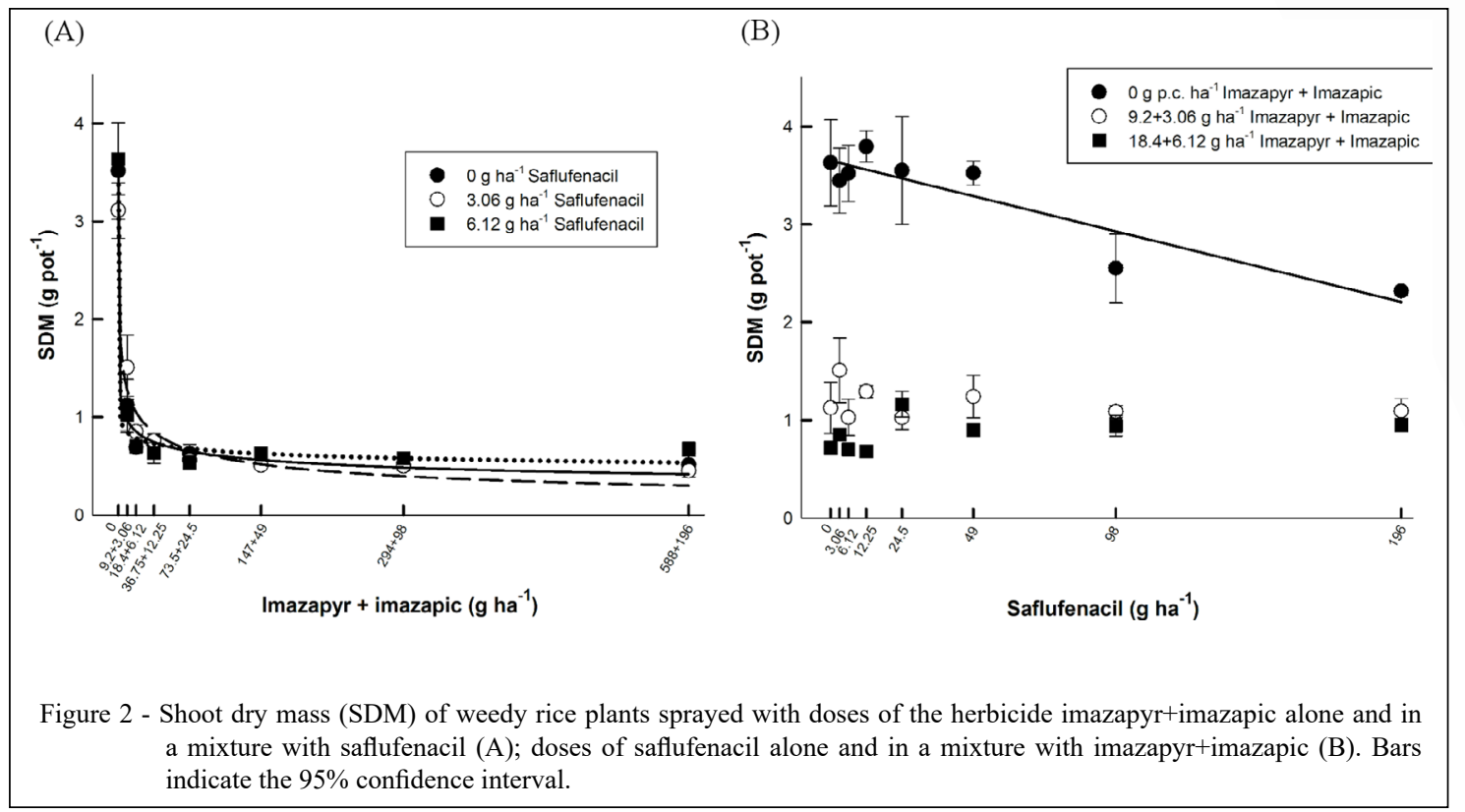

corresponding to isolated, plus 3.06, $6.12 \mathrm{~g}$ ha ${ }^{1}$ saflufenacil, respectively; Table 2) were below the lowest dose of imazapyr+imazapic $\left(9.2+3.06 \mathrm{~g} \mathrm{ha}^{-1}\right)$, indicating the herbicide efficiency.

The isolated saflufenacil resulted in a reduction in SDM of the weedy rice (Figure 2B). However, about $40 \%$ reduction in the highest dose of this herbicide (196 $\mathrm{g} \mathrm{ha}^{-1}$ saflufenacil). When mixed with imazapyr+imazapic, the SDM decline was higher than $70 \%$, regardless of the saflufenacil dose. For this variable, it was not possible to calculate the $\mathrm{GR}_{50}$ values since the separate application of saflufenacil did not cause a reduction of $50 \%$ in the plants and, with the mixtures of imazapyr+imazapic, the reduction was higher than $70 \%$, with no differences.

In the field experiments in 2014/15 and 2015/16 growing seasons, the results of the barnyardgrass control for treatments with the isolated application of saflufenacil did not show a difference between evaluation periods (Tables 3 and 4). These results were expected since saflufenacil is recommended for the control of Magnoliopsida weeds (MONTGOMERY et al., 2014; WALSH et al., 2015). TROLOVE et al. (2011) also showed an inefficient control of monocotyledons when saflufenacil was applied at 70 and $105 \mathrm{~g} \mathrm{ha}^{-1}$. This behavior is likely related to the ability of weeds to metabolize these herbicides. Studies on the selectivity of saflufenacil in maize crop performed by GROSSMANN et al. (2011) showed that maize seedlings rapidly metabolized saflufenacil in non-phytotoxic compounds in the roots and shoots tissue, after $16 \mathrm{~h}$, in the treated leaf tissues of maize $96 \%$ of saflufenacil was metabolized. In pre emergence applications, the low translocation of rootabsorbed herbicide into the shoot tissue additionally favors the tolerance to saflufenacil. In addition, in leaf discs from corn treated with saflufenacil slight increases in protoporphyrin IX and hydrogen peroxide were reported, providing selectivity for the species (GROSSMANN et al., 2010).

On the $14^{\text {th }}$ DAAin the $2014 / 15$ growing season, the barnyardgrass control was higher than $80 \%$, both in the isolate application of imazapyr+imazapic and in the mixture with saflufenacil (Table 3). On the $28^{\text {th }}$ DAA, these treatments provided a control equal to or higher than $97 \%$. For this variable in both growing seasons, there was no difference in the barnyardgrass control between the treatments, with satisfactory control (above $80 \%$ ) at the lowest dose of imazapyr+imazapic $\left(36.75+12.25 \mathrm{~g} \mathrm{ha}^{-1}\right)$.

For 2015/16 growing season (Table 4) and concerning the barnyardgrass control on the $14^{\text {th }}$ and $28^{\text {th }}$ DAA, only the treatment with a lower dose of imazapyr+imazapic $\left(36.75+12.25 \mathrm{~g} \mathrm{ha}^{-1}\right)$ differed from the others, indicating a less efficient control. At all evaluation times and treatments, the control levels of barnyardgrass were above $80 \%$. The use of saflufenacil in the mixture with imazapyr+imazapic did not interfere in the barnyardgrass control. 
Table 3 - Barnyardgrass (Echinochloa spp.) control due to the application of saflufenacil and imazapyr+imazapic herbicides at 14 and 28 days after application (DAA), and grain yield of the cultivar Puitá INTA CL. FAEM/UFPel. Capão do Leão/RS, in the 2014/15 growing season.

\begin{tabular}{|c|c|c|c|c|}
\hline \multirow[b]{2}{*}{ Treatment } & \multirow[b]{2}{*}{ Dose $\left(\mathrm{g} \mathrm{ha}^{-1}\right)$} & \multicolumn{2}{|c|}{-----'--'Control (\%)----------- } & \multirow[b]{2}{*}{ Grain yield $\left(\mathrm{kg} \mathrm{ha}^{-1}\right)$} \\
\hline & & 14th DAA & 28th DAA & \\
\hline Untreated & - & $0 b^{1}$ & $0 \mathrm{~b}$ & -2 \\
\hline Saflufenacil & 21 & $0 \mathrm{~b}$ & $0 \mathrm{~b}$ & - \\
\hline Saflufenacil & 42 & $0 \mathrm{~b}$ & $0 \mathrm{~b}$ & - \\
\hline $\mathrm{I}+\mathrm{I}$ & $36.75+12.25$ & $86 a$ & $98 \mathrm{a}$ & $9.377^{\mathrm{ns}}$ \\
\hline $\mathrm{I}+\mathrm{I}$ & $73.5+24.5$ & $90 \mathrm{a}$ & $100 \mathrm{a}$ & 8.757 \\
\hline $\mathrm{I}+\mathrm{I}$ & $110.25+36.75$ & $87 \mathrm{a}$ & $100 \mathrm{a}$ & 7.580 \\
\hline $\mathrm{I}+\mathrm{I}$ & $147+49$ & $86 a$ & $100 \mathrm{a}$ & 8.244 \\
\hline $\mathrm{S}+(\mathrm{I}+\mathrm{I})$ & $21+(36.75+12.25)$ & $90 \mathrm{a}$ & $98 \mathrm{a}$ & 7.808 \\
\hline $\mathrm{S}+(\mathrm{I}+\mathrm{I})$ & $21+(73.5+24.5)$ & $89 \mathrm{a}$ & $100 \mathrm{a}$ & 9.063 \\
\hline $\mathrm{S}+(\mathrm{I}+\mathrm{I})$ & $21+(110.25+36.75)$ & $90 \mathrm{a}$ & $100 \mathrm{a}$ & 8.763 \\
\hline $\mathrm{S}+(\mathrm{I}+\mathrm{I})$ & $21+(147+49)$ & $86 \mathrm{a}$ & $100 \mathrm{a}$ & 9.480 \\
\hline $\mathrm{S}+(\mathrm{I}+\mathrm{I})$ & $42+(36.75+12.25)$ & $88 \mathrm{a}$ & $97 \mathrm{a}$ & 7.870 \\
\hline $\mathrm{S}+(\mathrm{I}+\mathrm{I})$ & $42+(73.5+24.5)$ & $93 \mathrm{a}$ & $99 \mathrm{a}$ & 8.059 \\
\hline $\mathrm{S}+(\mathrm{I}+\mathrm{I})$ & $42+(110.25+36.75)$ & $88 \mathrm{a}$ & $100 \mathrm{a}$ & 9.737 \\
\hline $\mathrm{S}+(\mathrm{I}+\mathrm{I})$ & $42+(147+49)$ & $81 \mathrm{a}$ & $100 \mathrm{a}$ & 9.273 \\
\hline CV $(\%)$ & & 9.1 & 2.2 & 10.9 \\
\hline
\end{tabular}

${ }^{1}$ Means with different letters in the columns are significantly different according to the Tukey test $(\mathrm{P} \leq 0.05) .{ }^{2} \mathrm{Data}$ not collected due to the lodging of the crop caused by the high level of infestation of weeds that caused severe damage to the growth and development of the crop. ${ }^{n s}$ F non-significant test $(\mathrm{P} \leq 0.05)$.

In this study, the control obtained as a function of spraying only imazapyr+imazapic was equivalent to the treatments where these doses were combined with saflufenacil (Figure 1, tables 3 and 4). In these experiments, adding saflufenacil did not alter the weed control when compared to the herbicide imazapyr+imazapic alone, highlighting its neutral effect. These results differ from those of some previously published studies, where there was an antagonistic effect between Protox-inhibiting herbicides and ALS inhibitors (WESTBERG \& COBLE, 1992) or, more recently, which showed a synergistic effect between saflufenacil and imidazolinones (CAMARGO et al., 2012a; CAMARGO et al., 2012b; MONTGOMERY et al., 2015). It should be noted the in these studies saflufenacil was applied in a mixture with imazethapyr. Although, imazethapyr, imazapyr, and imazapic belong to the imidazolinone group, these molecules have small differences in their chemical and physical properties (SENSEMAN, 2007) which may explain the differences in results obtained when they are mixed with others herbicides molecules, such as saflufenacil. In addition, CAMARGO et al., 2012b, used a specific ecotype of weedy rice denominated TX4, which has a slight tolerance to imazethapyr, due to differential metabolism, absorption or translocation. In this ecotype, partial tissue necrosis caused by saflufenacil resulting from the peroxidation of cell membranes, can facilitate the movement of imazethapyr through the epicuticular layers to the cytoplasm by opening pores and channels of the plasma membrane.

Imazethapyr and saflufenacil in combination are synergic in the control of the weedy rice (CAMARGO et al., 2012a). A previous study showed that, in two evaluation periods in two years, there was an increase in the weedy rice control when imazethapyr was mixed with saflufenacil in comparison to imazethapyr applied alone (CAMARGO et al., 2012a). Similar effects were observed in the control of Echinochloa crus-galli, Sesbania herbacea, Ipomoea hederacea, and Amaranthus palmeri, where the use of the imazethapyr at $70 \mathrm{~g} \mathrm{ha}^{-1}$ mixed with saflufenacil at 50 $\mathrm{g} \mathrm{ha}^{-1}$ resulted in increased control of all these weeds, in comparison toimidazolinone alone (MONTGOMERY et al., 2015). Saflufenacil did not control weed grass species when applied alone (ANONYMOUS et al., 2013); however, the authors commented that this herbicide could cause injury to these species and that its emulsifiable concentrate formulation may favor the herbicidal effect (FISH et al., 2014; MONTGOMERY et al., 2015). Besides, when in combination with 
Table 4 - Barnyardgrass (Echinochloa spp.) control due to the application of saflufenacil and imazapyr+imazapic herbicides at 14 and 28 days after application (DAA), and grain yield of the cultivar Puitá INTA CL. FAEM/UFPel. Capão do Leão/RS in the 2015/16 growing season.

\begin{tabular}{|c|c|c|c|c|}
\hline \multirow{2}{*}{ Treatment } & \multirow[b]{2}{*}{ Dose $\left(\mathrm{g} \mathrm{ha}^{-1}\right)$} & \multicolumn{2}{|c|}{------------Control (\%)---------- } & \multirow[b]{2}{*}{ Grain yield $\left(\mathrm{kg} \mathrm{ha}^{-1}\right)$} \\
\hline & & 14th DAA & 28th DAA & \\
\hline Untreated & - & $0 \mathrm{c}^{1}$ & $0 \mathrm{~d}$ & $-{ }^{2}$ \\
\hline Saflufenacil & 21 & $0 \mathrm{c}$ & $0 \mathrm{~d}$ & - \\
\hline Saflufenacil & 42 & $0 \mathrm{c}$ & $0 \mathrm{~d}$ & - \\
\hline $\mathrm{I}+\mathrm{I}$ & $36.75+12.25$ & $83 \mathrm{~b}$ & $91 \mathrm{c}$ & $7.177 \mathrm{~d}$ \\
\hline $\mathrm{I}+\mathrm{I}$ & $73.5+24.5$ & $89 \mathrm{ab}$ & $99 \mathrm{ab}$ & $9.986 \mathrm{a}$ \\
\hline $\mathrm{I}+\mathrm{I}$ & $110.25+36.75$ & $94 \mathrm{a}$ & $96 \mathrm{abc}$ & $9.360 \mathrm{ab}$ \\
\hline $\mathrm{I}+\mathrm{I}$ & $147+49$ & 94 a & $100 \mathrm{a}$ & $8.136 \mathrm{bcd}$ \\
\hline $\mathrm{S}+(\mathrm{I}+\mathrm{I})$ & $21+(36.75+12.25)$ & $89 \mathrm{ab}$ & $94 \mathrm{bc}$ & $7.908 \mathrm{~cd}$ \\
\hline $\mathrm{S}+(\mathrm{I}+\mathrm{I})$ & $21+(73.5+24.5)$ & $91 \mathrm{a}$ & $99 \mathrm{ab}$ & $9.078 \mathrm{abc}$ \\
\hline $\mathrm{S}+(\mathrm{I}+\mathrm{I})$ & $21+(110.25+36.75)$ & $91 \mathrm{a}$ & $100 \mathrm{a}$ & $9.831 \mathrm{a}$ \\
\hline $\mathrm{S}+(\mathrm{I}+\mathrm{I})$ & $21+(147+49)$ & $95 \mathrm{a}$ & $100 \mathrm{a}$ & $9.881 \mathrm{a}$ \\
\hline $\mathrm{S}+(\mathrm{I}+\mathrm{I})$ & $42+(36.75+12.25)$ & $88 \mathrm{ab}$ & $96 a b c$ & $7.727 \mathrm{~cd}$ \\
\hline $\mathrm{S}+(\mathrm{I}+\mathrm{I})$ & $42+(73.5+24.5)$ & $93 \mathrm{a}$ & $100 \mathrm{a}$ & $9.083 \mathrm{abc}$ \\
\hline $\mathrm{S}+(\mathrm{I}+\mathrm{I})$ & $42+(110.25+36.75)$ & $93 \mathrm{a}$ & $99 \mathrm{ab}$ & $9.475 \mathrm{ab}$ \\
\hline $\mathrm{S}+(\mathrm{I}+\mathrm{I})$ & $42+(147+49)$ & $93 \mathrm{a}$ & $99 \mathrm{ab}$ & $9.987 \mathrm{a}$ \\
\hline CV $(\%)$ & & 4.5 & 3.0 & 6.3 \\
\hline
\end{tabular}

${ }^{1}$ Means with different letters in the columns are significantly different according to the Tukey test $(\mathrm{P} \leq 0.05) .{ }^{2} \mathrm{Data}$ not collected due to the lodging of the crop caused by the high level of infestation of weeds that caused severe damage to the growth and development of the crop.

saflufenacil, imazethapyr had an increase in 30 and $35 \%$ the uptake and translocation; respectively, in weedy ricewhen compared to the herbicide alone, thus increasing weed grass control (CAMARGO et al., 2012b).

Treatments without herbicide (control) and with separate application of 21 and $42 \mathrm{~g} \mathrm{ha}^{-1}$ of saflufenacil showed a high level of barnyardgrass infestation in both 2014/15 and 2015/16 crops (Table 3 and 4), leading to a severe lodging of cultivated rice plants, which made it impossible to evaluate these treatments concerning the grain yield parameter. In the 2014/15 growing season (Table 3), there was no significant difference in grain yield for other treatments. The highest absolute yield $\left(9.737 \mathrm{~kg} \mathrm{ha}^{-1}\right)$ was provided by the mixture of $42 \mathrm{~g} \mathrm{ha}^{-1}$ of saflufenacil $+(110.25+36.75) \mathrm{g} \mathrm{ha}^{-1}$ of imazapyr+imazapic. In the $2015 / 16$ growing season (Table 4), there were differences in the yield variable between treatments. The lowest grain yields were observed in the treatments with a lower dose of imazapyr+imazapic $\left(36.75+12.25 \mathrm{~g} \mathrm{ha}^{-1}\right)$, either in the isolated $(7.177$ $\left.\mathrm{kg} \mathrm{ha}^{-1}\right)$ or mixed treatments with saflufenacil (21 and $42 \mathrm{~g} \mathrm{ha}^{-1}$ ) with yields of 7.908 and $7.727 \mathrm{~kg} \mathrm{ha}^{-}$ ${ }^{1}$, respectively. In the imazapyr+imazapic isolated at
$147+49 \mathrm{~g} \mathrm{ha}^{-1}$, the grain yield $\left(8.136 \mathrm{~kg} \mathrm{ha}^{-1}\right)$ was lower than the intermediate doses of this herbicide $\left(73.5+24.5\right.$ and $\left.110.25+36.75 \mathrm{~g} \mathrm{ha}^{-1}\right)$ with 9.986 and $9.360 \mathrm{~kg} \mathrm{ha}^{-1}$, respectively. In this research, neither injury (results not shown) nor reduction in the rice yield grain related to the mixture of imazapyr+imazapic with saflufenacil was observed. Previous studies had indicated post-emergence saflufenacil injuries in other Poaceae species, such as wheat (Triticum aestivum L.) and barley (Hordeum vulgare L.), which directly reflected the reduction of $13 \%$ and $24 \%$ in grain yield, respectively (SIKKEMA et al., 2008). However, studies with rice cultivars showed that there was no reduction in the grain yield when spraying a mix of saflufenacil and imidazolinones (CAMARGO et al., 2012a, MONTGOMERY et al., 2014). In the tested rice cultivars; although, there were injuries of up to $20 \%$ with the application of saflufenacil, rapid growth and crop management (such as $\mathrm{N}$ fertilization) allowed plant recovery and did not cause grain yield losses.

\section{CONCLUSION}

In the mixture with imazapyr+imazapic, the saflufenacil herbicide did not interfere in the action of 
imidazolinones in the weedy rice and barnyardgrass control. Saflufenacil did not lead to injury or loss of yield when mixed with imazapyr+imazapic. The Puitá INTA CL rice cultivar was tolerant of the tested herbicides, either alone or in a mixture.

\section{ACKNOWLEDGMENTS}

To Conselho Nacional de Desenvolvimento Científico e Tecnológico (CNPq) for the Research Fellowship of Luis Antonio de Avila/N.Proc. 310538/2015-7 CNPq; "This study was financed in part by the Coordenação de Aperfeiçoamento de Pessoal de Nível Superior - Brasil (CAPES) - Finance Code 001",

\section{DECLARATION OF CONFLICT OF INTEREST}

The authors declare no conflict of interest. The founding sponsors had no role in the design of the study; in the collection, analyses, or interpretation of data; in the writing of the manuscript, and in the decision to publish the results.

\section{AUTHORS' CONTRIBUTIONS}

All authors contributed equally for the conception and writing of the manuscript. All authors critically revised the manuscript and approved of the final version.

\section{REFERENCES}

ANONYMOUS (2013). Aim herbicide label. Available from: $<$ http://www.greenbook.net>. Accessed: Aug. 12, 2018

CAMARGO, E.R. et al. Rice (Oryza sativa L.) response and weed control from tank-mix applications of saflufenacil and imazethapyr. Crop Protection, v.31, n.1, p.94-98, 2012a. Available from: <https://www.sciencedirect.com/science/article/ pii/S0261219411003073>. Accessed: Sep. 30, 2019. doi: 10.1016/j. cropro.2011.09.015.

CAMARGO, E.R. et al. Interaction between saflufenacil and imazethapyr in red rice (Oryza ssp.) and hemp sesbania (Sesbania exaltata) as affected by light intensity. Pest Management Science, v.68, n.7, p.1010-1018, 2012b. Available from: <https:// onlinelibrary.wiley.com/doi/abs/10.1002/ps.3260>. Accessed: Sep. 30, 2019. doi: $10.1002 /$ ps. 3260 .

CARLSON, T. P. et al. Imazethapyr plus propanil programs in imidazolinone-resistant rice. Weed Technology, v. 25, n.2, p.204 211, 2011. doi: 10.1614/WT-D-10-00118.1.

COLBY, A. S. R. Calculating synergistic and antagonistic responses of herbicide combinations. Weed Science Society of America, v.15, n.1, p.20-22, 1967.

CONCENÇO, G. et al. Control of jointvetch (Aeschynomene spp.), establishment and productivity of rice as a function of [imazapic + imazapyr] doses. Journal of Agricultural Science, v.10, n.4, p.287-296, 2018. doi: 10.5539/jas.v10n4p287.

COUNCE, P. A. et al. A uniform, objective, and adaptive system for expressing ricedevelopment.Crop Science, v.40,p.436-443,2000.Available from: $\quad<\mathrm{https}: / / \mathrm{dl}$.sciencesocieties.org/publications/cs/pdfs/40/2/436>.
Accessed: Sep. 30, 2019. doi: 10.2135/cropsci2000.402436x.

DAMALAS, C. A. Herbicide tank mixtures: common interactions. International Journal of Agriculture \& Biology, v. 6, n. 1, p. 209-212, 2004.

DAYAN, F. E.; WATSON, S. B. Plant cell membrane as a marker for light-dependent and light-independent herbicide mechanisms of action. Pesticide Biochemistry and Physiology, v.101, p.182190, 2011. doi: 10.1016/j.pestbp.2011.09.004.

FISH, J.C. et al. Potential of saflufenacil in Clearfield rice. Rice Technical Working Group Annual Meeting, v.1, n.1, p.18-21, 2014.

FISH, J. C. et al. Imazamox plus propanil mixtures for grass weed management in imidazolinone-resistant rice. Weed Technology, v. 30, n. 1, p.29-35, 2016. doi: 10.1614/WT-D-15-00027.1.

GROSSMANN, K. et al. The herbicide saflufenacil (Kixor ${ }^{\mathrm{TM}}$ ) is a new inhibitor of protoporphyrinogen IX oxidase activity. Weed Science, v.58, n.1, p.1-9, 2010. doi: 10.1614/WS-D-09-00004.1.

GROSSMANN, K. et al. Saflufenacil (Kixor ${ }^{\mathrm{TM}}$ ): Biokinetic properties and mechanism of selectivity of a new protoporphyrinogen IX oxidase inhibiting herbicide. Weed Science, v.59, n.3, p.290-298, 2011. Available from: <https://www. cambridge.org/core/journals/weed-science/article/saflufenacilkixor-biokinetic-properties-and-mechanism-of-selectivity-ofa-new-protoporphyrinogen-ix-oxidase-inhibiting-herbicide/ A240DBBE6F664C1573F740FEA2047B48>. Accessed: Sep. 30, 2019. doi: 10.1614/WS-D-10-00179.1

HEAP, I. The international survey of herbicide resistant weeds. Available from: $<\mathrm{http}: / /$ www.weedscience.org $>$. Accessed: Aug. 8, 2018.

IRGA, Instituto Rio Grandense do Arroz. Available from: $<$ https://irga-admin.rs.gov.br/upload/arquivos/201811/09142119cultivares-10.pdf $>$. Accessed: Nov. 21, 2018.

KNEZEVIC, S.Z. et al. Adjuvants influenced saflufenacil efficacy on fall-emerging weeds. Weed Technology, v.23, n.3, p.340-345, 2010. Available from: <https://bioone.org/ journals/Weed-Technology/volume-23/issue-3/WT-08-174.1/ Adjuvants-Influenced-Saflufenacil-Efficacy-on-Fall-EmergingWeeds/10.1614/WT-08-174.1.short>. Accessed: Sep. 30, 2019. doi: 10.1614/WT-08-174.1.

KUDSK, P.; MATHIASSEN, S. K. Joint action of amino acid biosynthesis-inhibiting herbicides. Weed Research, v.44, n.4, p.313-322, 2004. doi: 10.1111/j.1365-3180.2004.00405.x.

KUMAR, V.; JHA, P.; JHALA, A. J. Confirmation of glyphosateresistant horseweed (Conyza canadensis) in montana cereal production and response to post herbicides. Weed Technology, v.31, n.6, p.799-810, 2017. doi: 10.1017/wet.2017.49.

LAZAROTO, C. A. et al. Susceptibility of three jointvetch species (Aeschynomene spp.) to the herbicide only. Revista Brasileira de Agrociência, v.14, n.4, p.117-120, 2008.

LIEBL, R.A. et al. BAS $800 \mathrm{H}$ : a new herbicide for preplant burndown and preemergence dicot weed control. Weed Science Society American, v.48, 120, 2008

MENEZES, V.G. et al. Association of glyphosate and imidazolinones on red rice control in Clearfield $^{\mathrm{TM}}$ rice. 
Ciência Rural, v.43, n12, p.2154-2159, 2013.Available from: $<$ http://www.scielo.br/scielo.php?script=sci arttext\&pid $=$ S0103-84782013001200006>. Accessed: Sep. 30, 2019. doi: $10.1590 / \mathrm{S} 0103-84782013001200006$.

MILLER, M. R.; NORSWORTHY, J. K. Florpyrauxifen-benzyl weed control spectrum and tank-mix compatibility with other commonly applied herbicides in rice. Weed Technology, p.1-7, 2018. doi: 10.1017/wet.2017.107.

MONTGOMERY, G.B. et al. Response of commercial rice cultivars to postemergence applications of saflufenacil. Weed Technology, v.28, n.4, p.679-684, 2014. Available from: <https://bioone.org/ journals/Weed-Technology/volume-28/issue-4/WT-D-14-00053.1/ Response-of-Commercial-Rice-Cultivars-to-PostemergenceApplications-of-Saflufenacil/10.1614/WT-D-14-00053.1.short>. Accessed: Sep. 30, 2019. doi: 10.1614/WT-D-14-00053.1.

MONTGOMERY, G.B. et al. Utilization of saflufenacil in a Clearfield $^{\circledR}$ rice (Oryza sativa) system. Weed Technology, v.29, n.2, p.255-262, 2015. Available from: <https://bioone.org/ journals/Weed-Technology/volume-29/issue-2/WT-D-14-00091.1/ Utilization-of-Saflufenacil-in-a-Clearfield-Rice-Oryza-sativaSystem/10.1614/WT-D-14-00091.1.short>. Accessed: Sep. 30, 2019. doi: 10.1614/WT-D-14-00091.1.

MOURA, D. S. et al. Multiple resistance of Sagittaria montevidensis biotypes to acetolactate synthase and photosystem II inhibiting herbicides. Planta Daninha, v.33, n.4, p.779-786, 2015. doi: 10.1590/S0100-83582015000400016.

MOURA, D.S. et al. Chemical control of california arrowhead (Sagittaria montevidensis) resistant to acetolactate synthase and photosystem II inhibiting herbicides in irrigated rice. Ciência Rural, v.46, n.12, p.2084-2089, 2016. Available from: $\quad<$ http://www.scielo.br/scielo.php?script=sci_arttext\&pid $=$ S0103-84782016001202084 $>$. Accessed: Sep. 30, 2019. doi: 10.1590/0103-8478cr20160117.

NELSON, K. A. et al. Weed control in soybean (Glycine max) with imazamox and imazethapyr. Weed Science, v.46, n.2, p.587-594, 1998. Available from: <https://www.jstor.org/stable/4045966>. Accessed: Sep. 30, 2019.

NUNES, F.S. et. al. Weed phytosociological survey in irrigated rice. Planta daninha, v.36, n.1, 2018. Available from: $\quad<$ http://www.scielo.br/scielo.php?script=sci_arttext\&pid $=$ S0100-83582018000100245 $>$. Accessed: Sep. 30, 2019. doi: $10.1590 / \mathrm{s} 0100-83582018360100044$.

PELLERIN, K. J. et al. Herbicide mixtures in water-seeded imidazolinone-resistant rice (Oryza sativa). Weed Technology, v. 17, n. 4, p. 836-841, 2003. doi: 10.1614/wt-03-007r1.

PELLERIN, K. J. et al. Potential use of imazethapyr mixtures in drill-seeded imidazolinone-resistant rice. Weed Technology, v.18, n.4, p.1037-1042, 2004. doi: 10.1614/WT-03-214.

PETTER, F. A.et. al. Physical incompatibility of herbicide and insecticide mixtures. Planta Daninha, v.30, n.2, p.449-457, 2012. Available from: $<$ http://www.scielo.br/scielo.php?script=sci abstract\&pid $=\mathrm{S} 0100-83582012000200025 \& \operatorname{lng}=\mathrm{en} \& \mathrm{nrm}=\mathrm{iso}>$. Accessed: Sep. 30, 2019. doi: 10.1590/S0100-83582012000200025.
SENSEMAN, S. A. Herbicide Handbook. 9. ed. Lawrence: Weed Science Society of America, 458p, 2007.

SIKKEMA, P. H. et al. Tolerance of spring barley (Hordeum vulgare L.), oats (Avena sativa L.) and wheat (Triticum aestivum L.) to saflufenacil. Crop Protection, v.27, p.1495-1497, 2008. Available from: <https://www.sciencedirect.com/science/ article/pii/S0261219408001270>. Accessed: Sep. 30, 2019. doi: 10.1016/j.cropro.2008.07.009.

SOLTANI, N.et. al. Response of corn to preemergence and postemergence applications of saflufenacil. Weed Technology, v.23, n.3, p.331-334, 2009. Available from: <https://bioone.org/ journals/Weed-Technology/volume-23/issue-3/WT-08-120.1/ Response-of-Corn-to-Preemergence-and-PostemergenceApplications-of-Saflufenacil/10.1614/WT-08-120.1.full>. Accessed: Sep. 30, 2019. doi: 10.1614/WT-08-120.1.

SOSBAI. Sociedade Sul-Brasileira de Arroz Irrigado. Arroz Irrigado: Recomendações técnicas da pesquisa para o sul do Brasil. Santa Maria, 2014. 192p. Available from: <http:// www.sosbai.com.br/docs/Boletim RT 2014.pdf>. Accessed: Sep. 30, 2019.

SOSBAI. Sociedade Sul-Brasileira de Arroz Irrigado. Arroz Irrigado: Recomendações técnicas da pesquisa para o sul do Brasil. Cachoeirinha, 2018. 205p. Available from: $<$ http://www.sosbai.com. br/docs/Boletim RT 2018.pdf>. Accessed: Sep. 30, 2019.

TROLOVE, M.R. et al. Efficacy and crop selectivity of saflufenacil alone and with partner herbicides for weed control in maize. New Zealand Plant Protection, v.64, p.133-141, 2011. Available from: $<$ http://journal.nzpps.org/index.php/nzpp/article/view/6012>. Accessed: Sep. 30, 2019. doi: 10.30843/nzpp.2011.64.6012.

UNLAND, R.D. et al. Interactions between imazamox and diphenylethers. Weed Science, v.47, n.4, p.462-466, 1999. Available from: <https://www.cambridge.org/core/journals/weedscience/article/interactions-between-imazamox-and-diphenylethe rs/942D74BB0DF05F26AE0D031FDF7658B7>. Accessed: Sep. 30, 2019. doi: 10.1017/S0043174500092080.

VARGAS, L. et al. Rapid detection of horseweed and black picker sensitivity levels to saflufenacil. Planta daninha, v.37, p.1-7, 2019. doi: 10.1590/S0100-83582019370100022.

WALSH, K.D. et al. Weed control in soybean with imazethapyr applied alone or in tank mix with saflufenacil/dimethenamid-P. Weed Science, v.63, n.1, p.329-335, 2015. Available from: $<$ https://bioone.org/journals/Weed-Science/volume-63/issue-1/ WS-D-14-00076.1/Weed-Control-in-Soybean-with-ImazethapyrApplied-Alone-or-in/10.1614/WS-D-14-00076.1.full>. Accessed: Sep. 30, 2019. doi: 10.1614/WS-D-14-00076.1.

WESTBERG, D.E.; COBLE, H.D. Effect of acifluorfen on the absorption, translocation, and metabolism of chlorimuron in certain weeds. Weed Technology, v.6, n.1, p.4-12, 1992. Availablefrom: $<$ https://www.cambridge.org/core/journals/weed-technology/ article/effect-of-acifluorfen-on-the-absorption-translocation-andmetabolism-of-chlorimuron-in-certain-weeds/B632229384666FE 065EC4B9AAA595F84>. Accessed: Sep. 30, 2019. doi: 10.1017/ S0890037X00034217. 